Journal of Qualitative Criminal Justice \& Criminology

\title{
Historical Book Review | \\ The Jack-Roller: A \\ Delinquent Boy's Own \\ Story
}

Richard Tewskbury ${ }^{1}$

${ }^{1}$ University of Louisville

Published on: Aug 01, 2014

DOI: 10.21428/88de04a1.4465b3c3

License: Creative Commons Attribution 4.0 International License (CC-BY 4.0). 
Clifford Shaw. The Jack Roller: A Delinquent Boy's Own Story. University of Chicago Press, 1930; 205 pp.; ISBN: 0226751260.

Learn from the classics. Understand where you came from. Know the past so you won't repeat it. Be informed about those that have preceded you. Find the foundation your own work is based upon. All of these are viable, valuable, and unfortunately, often unheeded pearls of wisdom. I, for one, can admit that while I've espoused these lessons many times, I have not adhered to my own advice. Although we all are well versed (at least for an undergraduate level lecture or two) on the history of our field and the influential scholars and works of the field, unfortunately far too many of us have ignored or simply glossed over the classics in criminology and criminal justice. From that perspective I approached the task of reading and reviewing Clifford Shaw's The Jack Roller.

What I found when I read this book-yes, admittedly for the first time-was a text rich with ideas, theoretical concepts, and evidence to support many of our present day theories and beliefs about crime, criminals, and criminal justice. Yes, the book was published nearly one hundred years ago (1930), and at times the language appears outdated and quaint; some particulars of the stories reference processes and structures that have changed significantly (riding street cars, working for 33 cents/hour, etc.); however, the first person narrative style, the core ideas, and understandings are consistent with today's experiences. If nothing else, the reading provides evidence to support nearly any contemporary theory of criminology.

The Jack Roller is a book about a young criminal, Stanley, and his early-inlife development of delinquent and criminal ways. Through a retrospective account of his life, Stanley offers readers insights into his personality, his thinking patterns, his social world, and what readers can quickly see as the universality of social forces that create, maintain, occasionally intensify, and sometimes attempt to ameliorate delinquent and criminal behaviors. Stanley is not just a product of his environment or his historical time, Stanley is more. In a reading of The Jack Roller today, one is shown that there is a core set of social experiences that constitute being a small-time, chronic offender. This stands then at the core of what we endeavor to understand in our discipline, why does crime happen? Here we look at the small time offender, one easily characterized as a social nuisance and bothersome, although not necessarily dangerous or predatory. Stanley is a regular criminal, not an extreme case, not a high profile offender. To read about and understand Stanley's life and criminal career is to understand how and why crime happens. To see the beginning of delinquency and criminality is to see it at its foundation. Stanley is the vessel for teaching the fundamentals of criminology, even though Shaw undoubtedly never realized the ubiquity of Stanley's story for his time, or the subsequent century. 
The story of Stanley begins with his dabbling in theft and truancy at the age of 6 . Due to the death of his mother and his father's remarriage, Stanley finds himself in a new world, with new people, and new social norms. Stanley's inability to adapt to the new social context turns his attention outward and pushes him toward his (older) peers and their subcultural ways of life. Through attempts to escape an overcrowded, poor, and abusive home, Stanley turns to the streets of Chicago for exciting adventures, numerous repeated encounters with the police, court interventions, and periods of brief incarceration and in so doing, develops into an independent, self-reliant, rebellious, and authority-resisting adolescent. Within 10 short years, Stanley goes from being yet another forgotten-about child in poverty to being a skilled thief, burglar, and robber (jack rolling drunks) with an advanced education in living and surviving in jail, prison, and on the streets. Stanley encounters numerous officials (sometimes caring and sometimes indifferent) as well as socially conscious and well-intended community members and officials who intervene on his behalf. As we know today, sometimes these interventions work, sometimes they do not. For most of Stanley's life, the interventions are both minimal and ineffective. Yes, incarceration and caring interventions sometimes help him out, but only for a short period. The lasting effects of any interventions are not realized, largely because the interventions are simplistic or last only a specified length of time, and then Stanley is "free" once again. Coupled with treatment in what he perceived as either abusive or overly rigid institutions, Stanley develops a resentment of authority and a life view absent the ability to see long term. In the end, as a result of the intervention of "Mr. Shaw" and his resources, redemption is achieved. At the same time, the effective interventions come at about the time in life that we know criminals age out of offending. Considering his stage of life (not chronological age), Stanley does more or less age out of his criminal ways, finds love and support in a family setting, and establishes a life in a mainstream, noncriminal, supportive family and community. Seemingly, Stanley ends with the American dream.

While a very enjoyable and realistic read, it is not the particulars of Stanley's story that are the primary contribution of this book. What stands, at least today, as the big contributions of The Jack Roller are two issues. First, the story of delinquency and crime in the 1920s and 1930s transcends time and could very, very easily be a story from the 1990s or today. Second, reading a classic such as this reminds and reinforces for scholars the contributions that can be gained by seeing the insights afforded through a life history method and appreciating that we can make arguments, propose and support theory, and make conclusions about the efficacy and efficiency of structured criminal justice and other processes without statistics and citations. The story of Stanley is educational and convincing, but completely devoid of contemporary indicators of quality of research or scientific proof.

The timelessness of the story is the first thing that struck me as I read this. I opened the book thinking it would be different and quaint, because it reflects a socio-historical period in which day to day life was very different from today. However, I found a story and issues that were familiar and predictable, because of the parallels to what we know about crime and criminals today. Certainly the fact that 
Stanley's juvenile parole officer was one of two for the city of Chicago would be astonishing today, but the challenges of his parole officer (large caseloads, few alternatives for responding to violations, communications difficulties with clients and other system agencies) are those we still know today. Throughout his young life, Stanley frequently relies on stealing for daily survival, for there are no or no reliable social services to provide him with a stable and safe lifestyle. Today, our ex-offenders face similar circumstances. Today, we may have reliable transportation, cell phones, and instant access to almost any information at our fingertips, but the problems and challenges of managing stigma, a lack of resources, and bureaucratic organizations that have a limited scope of influence all persist. What we know today is seen clearly and consistently in the experiences recounted here, from nearly a century ago.

As a criminologist, it would be impossible to read the text and not repeatedly have "aha!" moments. Throughout Stanley's story there are incidents and his own reflexive observations that point to the issues and theories we know so well today. In every instance and every story, there are issues of social learning, differential association, social control theory, labeling, biological and cultural issues, and many more. Whether it is Stanley consciously rebelling against his abusive step-mother and leaving the house to find someone upon whom to take out his frustrations, or when he is essentially sitting at the feet of older, wiser, more-criminally involved inmates and learning their stories and techniques of stealing, or at times when he is reminiscing about how only his old friends in the old neighborhood can understand him-these are clearly incidents reflective of our theories of crime today. And although such points are obvious and rather blatant today, for those who do not catch the significance of such events, Shaw steps in to point out such theoretical points in well placed footnotes throughout the text. This is done in a manner to help the reader and serve as a reminder of the relevance of a point, not as a way to cite sources or name issues. Even those readers who get caught up in the minutiae of Stanley's life story will come away with insights and understandings of the why for Stanley's criminality.

The second significant contribution of this book today is that it serves as a reminder that understanding crime, criminals, and justice agencies is our goal, and that we can achieve that goal in many ways. The Jack Roller is a book about a boy, one boy, and his context-specific challenges, behaviors, and thoughts. And when taken as a whole, it is easy to see the ways that these specifics aggregate to produce the man that Stanley becomes. We learn why by being shown why. We do not learn why by reading about others or commonalities of offenders or variables and their isolated effects on behavior. There are no citations to prove the points that Shaw presents; there is only the case study and its particulars. Readers are not introduced to a theory, and there is no explanation of how specifics fit or do not fit a particular theory. There is only the well told story of events and how Stanley experienced them. Viewing his attempts to maneuver in the social, economic, political, and cultural context of his time and place provides an understanding of who he is, how he feels, and why he behaves as he does. Yet, despite the fact that Shaw avoids coming out to tell us why and how Stanley 
became the criminal he did, readers come away having seen it happen through Stanley's eyes. As such, a different depth of understanding develops; the reader truly knows how it is that Stanley ended up who he is and why his life progresses in the steps that are taken. Shaw teaches his readers, but in a subtle, conversational, and easy to read way.

As I completed the text, I could not help but think "I should read more stuff like this." But, the fact is, I do read a lot of qualitative, especially ethnographic, work. But, very rarely do I remember reading something that allowed me to come away thinking that everything made sense and all fit together very nicely. Many of the books that my graduate students read lead them to point out weaknesses in an argument or places where arguments are weakened or broken. Here where there are "just the facts" of the case laid out, this may be less likely to occur. So, logically then, why do we not have students read things like this anymore? Yes, we have newer, more historically relevant to today, theoretically rich and driven accounts of crime and criminals. But, do we have things that teach us without us realizing it? Do we have texts that show that to understand is what we are striving for, and that we can get to that point without hypotheses, research questions, careful operationalization of variables, and all of the other newest, shiniest, most impressive techniques for collecting and analyzing data? Such texts today would seem few and far between. However, here in one of the classics-a book that nearly all criminology students have certainly heard of, but probably never read-is exactly that type of text.

Students and scholars would be well advised to return to the classics, not so much so as to learn what we do not yet know, but to be reminded about what we do our studies for, and how perhaps our best evidence may be seen in identifying commonalities across time and settings and particulars. It is in this realization-with only a few details about stories adjusted-that we can identify processes, structures, and interactions which serve as the foundation for the causes of crime.

The knowledge for which we strive is more universal than we sometimes remember and definitely more universal than whatever statistical sense of generalizability that we may (or may not) be able to achieve with our advanced methodologies of today. The Jack Roller served to remind me of this and to reinforce the idea that we can learn and make convincing arguments in many different ways. Perhaps we need to revisit the classics. Perhaps today's budding criminological scholars should be exposed to the classics and not just as a sentence or two in an introductory book. To look back at from where we have come can be extremely beneficial. If we want to advance in our understandings and approaches, sometimes we need to go back to the beginning and remind ourselves of how and why we embarked on our quest for knowledge and understanding in the first place. To (re)read the classics is to be reminded of our past and to have our grasp and means of working in the present reinforced.

Clifford Shaw's The Jack Roller is a book I am very happy I (finally) read. My students will be reading it, too. I am certain that at least initially they will protest and claim to not understand why such an old book would be relevant to their lives and learning. But once they begin, I am certain that the 
recognition of concepts, theories, and understandings we have about crime, criminals, and criminal justice will be sparked, and they will come to appreciate how the basics of an argument remain relevant in the 21st century. 